ORIGINAL ARTICLE / ARTIGO ORIGINAL

\title{
Active aging is associated with low prevalence of depressive symptoms among Brazilian older adults
}

\author{
Envelhecimento ativo está associado com baixa prevalência \\ de sintomas depressivos em idosos brasileiros
}

Rosangela Galli', Emílio Hideyuki Moriguchi',"I, Neide Maria Bruscato'"', Rogerio Lessa Horta', Marcos Pascoal Pattussi'

\begin{abstract}
Introduction: Active aging is the process of optimizing opportunities for health, participation and security, aiming to improve quality of life as people age. A series of studies had demonstrated that a lower prevalence of depression is found among more active elderly. Objective: To evaluate the association between indicators of active aging and depressive symptoms among the elderly (aged 60 years or more). Method: A population-based cross-sectional study was conducted with 1,006 elderly people (aged 60 years or over) from a small-sized Brazilian municipality. Depressive symptoms were assessed using the Geriatric Depression Scale 15 , with cutoff point $\geq 6$ symptoms. Active aging was evaluated using indicators such as: active occupational situation, manual work, reading and physical activities. Data analyses used modified Poisson regression to obtain crude and adjusted prevalence ratios (PR). Results: Most of the elderly people were: white, women and aged between 60 and 74 years. All the indicators of active aging were associated with the outcome. After controlling for socioeconomic, demographic and health variables, elderly people who worked, participated in groups, did manual work and maintained interests such as reading and talking to friends had lower prevalence of depressive symptoms compared to those not doing these activities. Conclusions: Active aging approaches may serve as a valuable mental health promotion strategy aimed at the elderly.
\end{abstract}

Keywords: Depression. Aged. Aging. Depressive symptoms. Physical activity. Cross-sectional studies.

'Graduate program in Public Health, Universidade do Vale do Rio dos Sinos - São Leopoldo (RS), Brazil.

"School of Medicine, Universidade Federal do Rio Grande do Sul - Porto Alegre (RS), Brazil.

"'Associação Veranense de Assistência à Saúde, Hospital Comunitário São Peregrino Lazziozi - Veranópolis (RS), Brazil.

Corresponding author: Marcos Pascoal Pattussi. Programa de Pós-Graduação em Saúde Coletiva. Universidade do Vale do Rio dos Sinos. Avenida Unisinos, 950, Caixa Postal 275, CEP: 93022-000, São Leopoldo, RS. Brasil. E-mail: mppattussi@unisinos.br Conflict of interests: nothing to declare - Financial support: none. 
RESUMO: Introdução: Envelhecimento ativo é o processo de otimizar oportunidades para a saúde, participação e segurança, de modo a promover qualidade de vida enquanto as pessoas envelhecem. Estudos demonstram que menores prevalências de depressão são encontradas em idosos fisicamente ativos. Objetivo: Avaliar a associação entre indicadores de envelhecimento ativo e sintomas depressivos em idosos (60 ou mais anos de idade). Métodos: O delineamento foi transversal de base populacional. Entrevistas estruturadas foram realizadas com 1.006 idosos, pessoas com idade igual ou superior a 60 anos, residentes em um município de pequeno porte do Sul do Brasil. Sintomas depressivos foram mensurados através da Escala de Depressão Geriátrica com ponto de corte maior ou igual a seis pontos. O envelhecimento ativo foi avaliado com indicadores tais como: participação em grupos, situação ocupacional ativa, trabalhos manuais, leituras, conversa com amigos e atividades físicas. A análise dos dados utilizou Regressão de Poisson para obter as razões de prevalência (RP) brutas e ajustadas. Resultados: A maioria dos idosos eram mulheres, idade entre 60 e 74 anos e cor da pele branca. Todos os indicadores de envelhecimento ativo estavam associados com o desfecho. Após o controle para aspectos sociodemográficos, psicossociais e variáveis relacionadas à saúde, idosos com situação ocupacional ativa, que participavam em grupos, que relatavam realizar trabalhos manuais, com hábito de leitura e de socializar com os amigos possuíam menores prevalências de sintomas depressivos quando comparados àqueles que realizavam tais atividades. Conclusões: Abordagens com foco no envelhecimento ativo podem ser uma estratégia importante para promoção da saúde mental em idosos.

Palavras-chave: Depressão. Idosos. Envelhecimento. Sintomas depressivos. Estudo transversal.

\section{INTRODUCTION}

According to the World Health Organization, it is estimated that around $14 \%$ of the overall burden of disease is due to neuropsychiatric disorders ${ }^{1}$. A common mental disorder and one of the main causes of disability worldwide is depression. It is estimated that about 400 million people of all ages suffer from depression globally ${ }^{2,3}$. This especially important in more advanced ages.

Depressive syndromes in old age frequently occur within the context of medical and neurological disorders, and in elderly individuals with chronic diseases and cognitive deficiencies or functional disability ${ }^{4}$, thereby causing difficulties in achieving adequate treatment and increasing mortality ${ }^{4,5}$.

Among the elderly, depression generally presents atypical symptoms and is generally underdiagnosed and undertreated because of confusion with coexisting physical problems ${ }^{6,7}$. In addition, although many depressed elderly people are usually treated within primary care, healthcare professionals rarely diagnose depression and, when they do, the treatment provided is often inadequate ${ }^{5}$, since depressive symptoms are regarded as natural manifestations of aging ${ }^{7}$.

Although pharmacological treatment is generally effective among elderly people ${ }^{8}$, the side effects from antidepressants are greater among this population, because these individuals usually present comorbidities and risks of clinical complications and drug interactions. Therefore, initiatives that enable recovery without drug use are needed. In this context, the World Health Organization has proposed the concept of active aging as the process of optimizing opportunities for health, participation and security in order to improve quality of life as people age ${ }^{2}$. A series of studies had demonstrated that a lower prevalence of depression is found among physically active 
elderly people ${ }^{7,9}$. This study aimed to assess the association between indicators of active aging and depressive symptoms among elderly people. The hypothesis was that elderly people reporting active lives would also report fewer depressive symptoms compared to inactive individuals.

\section{METHODS}

This was a population-based, cross-sectional study with elderly people, i.e. individuals aged 60 years or over, living in the urban or rural zones of the municipality of Veranópolis, state of Rio Grande do Sul, in southern Brazil. This municipality is located in the northeastern State, $170 \mathrm{~km}$ from Porto Alegre. According to the Brazilian Institute of Geography and Statistics (IBGE), the municipality had 22,810 inhabitants in the year 2010; 3,493 were elderly individuals, which accounts for approximately $15.3 \%$ of the population, consisting mainly of Italian descendants.

The sample was calculated for another study, which used the outcome vaccination and the variable that provided the largest size (sex). Thus, assuming that the prevalence of vaccination among men was $67.1 \%$, with a female to male ratio of $1: 1$, a sample of 988 elderly people would be needed in order to have a power of $80 \%$ for detecting an odds ratio of 1.5 . After adding $15 \%$ to account for possible losses, 1,136 elderly individuals were invited to participate. For the outcome depression, the focus of this study, this sample size had a power of $80 \%$ to detect a difference of seven percentage points between exposed and non-exposed individuals, with a significance level of $5 \%$ and a $95 \%$ confidence interval.

The sample was selected by means of a systematic randomization process. To this end, a list of the eligible individuals (individuals aged 60 years or over), containing their names, addresses and telephone numbers, was obtained from the Municipal Health Department. The municipality has been targeted in several studies assessing successful aging among its elderly population, and keeps updated records of all elders residing in the town. Elderly people with severe cognitive problems or any disability or diseases that impeded them from answering the questionnaire were excluded from the sample.

Structured interviews were conducted at the elderly individuals' homes in 2009.

The outcome studied was assessed by means of the Geriatric Depression Scale. This is one of the most used screening instruments for depressive symptoms among elderly people. Several studies have shown that it provides valid and reliable measurements ${ }^{10-12}$. The original scale of 30 items was described in English by Yesavage et al. ${ }^{13}$ and was developed especially for the screening of mood disorders among elderly individuals, with questions that avoid the sphere of somatic complaints. Each response compatible with depression is given a score of one point. In this study, we reported data for the short version comprised of 15 items (GDS-15). Main results were presented for the cutoff $(5 / 6)$. This has been suggested as the optimal cutoff point for GDS-15 $5^{11,14}$. Thus, individuals were considered depressive if their score was six or more points ${ }^{11,14}$.

The demographic variables were sex, age (60 - 74 or $\geq 75$ years), skin color (white or black/mixed/other) and marital status (married, widowed or other). The socioeconomic variables were income in reais $(\mathrm{R} \$$ ) and schooling level (number of years of study). 
The health-related variables that were evaluated included self-rated health (excellent/ very good/good or fair/poor), number of morbidities reported ( $0,1,2$ or $\geq 3$ morbidities) and number of medical consultations in the last month ( 0,1 or $\geq 2$ consultations).

To assess active aging, a series of individual indicators was used asking if the following activities were done frequently: participation in groups (non-participation, or participation in one or more groups), occupational situation (working or not working), talking to friends (yes or no), doing manual work (yes or no), reading habit (yes or no) and physical activities (yes or no).

A pilot study was conducted with 20 elderly individuals who were not included in the sample for the main study. The aim of the pilot study was to test the instrument and the logistics of the study. Data gathering took place during the year 2009, and was done by a team composed of five interviewers who had been trained and standardized for carrying out the interviews.

Quality control was carried out by the coordinator of the study, by telephone, on a random sample of $10 \%$ of the individuals participating in the study. The control instrument was similar to that of the main study, but was shorter and included only the variables that would not undergo changes over a short space of time (e.g. sex, age, marital status, skin color, income, schooling). An acceptable agreement was achieved for all variables (kappa $>0.7$ ).

In order to avoid typing errors and data inconsistencies, double data entry was performed using the Epi Info 6.0 software. The data analysis was conducted using the STATA 9.0 software. To compare the prevalence of the outcomes between the exposure categories, the $\chi^{2}$ test was used. To provide an estimate for the crude and adjusted prevalence ratios and their respective confidence intervals, Poisson regression with robust variance was performed.

Multivariable analysis was carried out as follows: three blocks of variables were incorporated in the multivariable model. The first included the socioeconomic and demographic variables, the second included health- and healthcare-related variables and the third included the indicators of active aging. The variables were adjusted for all the other variables at the same block and plus the variables at higher blocks. A backward elimination procedure was adopted within each block. A two-tailed p-value of $<0.05$ was used for determining statistically significant associations. We run this analysis using three cutoff points frequently reported in the literature $(4 / 5),(5 / 6)$ and $(6 / 7)$.

This study was compliant to the ethical issues involved in studies of this nature, as laid down in Resolution 196/96 of the National Health Board. The research project was approved by the Ethics Committee of Universidade do Vale do Rio dos Sinos (Resolution 100, of December 18, 2008), and all the participants signed an informed consent. The authors state that there is no conflict of interest.

\section{RESULTS}

Out of the 1,136 elderly people initially envisaged for this study, 1,012 (89\%) actually participated in it. The main reasons for the losses were failure to locate individuals who appeared on the list supplied by the municipal authority (9.5\%), refusals $(1 \%)$ and deaths $(0.5 \%)$. 
In addition, five individuals had incomplete data regarding depressive symptoms. Therefore, the data analysis was conducted on 1,006 elderly people.

Most of the elderly people were: white, married and women. The mean age, income and educational level were, respectively: 73 years $(S D=4), R \$ 1,836.00(S D=170.00)$ and 5 years of education $(\mathrm{SD}=4)$.

Higher prevalence $(\mathrm{p}<0.05)$ of depressive symptoms was found among women, individuals aged 75 years or over, individuals with low income and low schooling levels and individuals with greater numbers of consultations, morbidities and reporting poor selfrated health. All indicators of active aging were associated with the outcome regardless the cutoff point adopted. Lower prevalence of depressive symptoms was found among elderly people who worked, did physical activities or manual work and maintained interest through reading and usually talked to friends (Table 1 ).

The multivariable analysis maintained the effect of the socioeconomic and demographic factors (sex, age, income), health-related variables (self-rated health, morbidities and medical consultations), and indicators of active aging (manual work, physical activities and reading). After controlling for socioeconomic, demographic and health related variables, elderly people who worked, participated in groups, did manual work and maintained interest through reading and talking to friends had lower prevalence of depressive symptoms (cutoff 5/6) compared to those not doing these activities (Table 2). Only participation in groups, reading habit and physical activity remained in the final model using the cutoff $6 / 7$ for depressive symptoms.

Table 1. Description of the sample and prevalence of depressive symptoms (GDS15, cutoff point $5 / 6$ ) according to the socioeconomic, demographic, health-related variables and indicators of active aging among elderly people in Veranópolis, RS, Brazil $(n=1,006)$.

\begin{tabular}{|c|c|c|c|}
\hline & $\mathrm{n}$ & $\begin{array}{c}\% \geq 6 \text { depressive } \\
\text { symptoms }\end{array}$ & $\mathrm{p}$-value \\
\hline \multicolumn{4}{|c|}{ Demographic } \\
\hline \multicolumn{4}{|l|}{ Sex } \\
\hline Male & 380 & 11.4 & $<0.001$ \\
\hline Female & 632 & 25.2 & \\
\hline \multicolumn{4}{|l|}{ Age } \\
\hline $60-74$ & 630 & 16.5 & $<0.001$ \\
\hline$\geq 75$ years & 382 & 26.0 & \\
\hline \multicolumn{4}{|l|}{ Marital status } \\
\hline Married & 647 & 15.0 & $<0.001$ \\
\hline Widower & 291 & 30.4 & \\
\hline Other & 73 & 23.6 & \\
\hline \multicolumn{4}{|l|}{ Skin color } \\
\hline White & 968 & 20.0 & 0.654 \\
\hline Black/Mixed/Other & 44 & 22.7 & \\
\hline
\end{tabular}


Table 1. Continuation.

\begin{tabular}{|c|c|c|c|}
\hline & $\mathrm{n}$ & $\begin{array}{c}\% \geq 6 \text { depressive } \\
\text { symptoms }\end{array}$ & p-value \\
\hline \multicolumn{4}{|c|}{ Socioeconomic } \\
\hline \multicolumn{4}{|l|}{ Family income $(R \$)$} \\
\hline High ( $\geq 2076)$ & 251 & 15.6 & $<0.001$ \\
\hline Middle (930 - 2075) & 539 & 17.7 & \\
\hline Low (0 - 929) & 222 & 30.9 & \\
\hline \multicolumn{4}{|l|}{ Schooling (years) } \\
\hline High ( $\geq 7)$ & 210 & 18.7 & 0.005 \\
\hline Middle $(3-6)$ & 589 & 17.7 & \\
\hline $\operatorname{Low}(0-2)$ & 209 & 28.2 & \\
\hline \multicolumn{4}{|c|}{ Health } \\
\hline \multicolumn{4}{|l|}{ Self-rated health } \\
\hline Excellent/very good/good & 541 & 9.6 & $<0.001$ \\
\hline Fair/poor & 470 & 32.1 & \\
\hline \multicolumn{4}{|l|}{ Morbidities } \\
\hline No morbidity & 242 & 10.0 & $<0.001$ \\
\hline 1 morbidity & 366 & 15.9 & \\
\hline 2 morbidities & 256 & 25.2 & \\
\hline$\geq 3$ morbidities & 147 & 38.4 & \\
\hline \multicolumn{4}{|l|}{ No. Medical appointments } \\
\hline No appointment & 564 & 16.8 & $<0.001$ \\
\hline 1 appointment & 378 & 22.3 & \\
\hline$\geq 2$ appointments & 69 & 34.8 & \\
\hline
\end{tabular}

Occupation status

Active aging

\begin{tabular}{|l|c|c|}
\hline Not-working & 946 & 21 \\
\hline Working & 64 & 6.3 \\
\hline
\end{tabular}

\section{Participation in groups}

\begin{tabular}{l|c|c|c}
\hline No & 652 & 25.7 & $<0.001$ \\
\hline $\begin{array}{l}\text { Yes } \\
\text { Talking to friends }\end{array}$ & 359 & 10.0 & \\
\hline No & 41 & 48.7 & $<0.001$ \\
\hline Yes & 969 & 18.9 & \\
\hline $\begin{array}{l}\text { Manual work } \\
\text { No }\end{array}$ & 527 & 24.3 & 0.001 \\
\hline Yes & 483 & 15.5 & \\
\hline Reading & 371 & & \\
\hline No & 639 & 28.9 & $<0.001$ \\
\hline Yes & & 15.0 & \\
\hline Physical Activity & & & \\
\hline No & 530 & 23.2 & $<0.001$ \\
\hline Yes & 580 & 10.3 & \\
\hline$\chi^{\text {Pea }}$ & & & \\
\hline
\end{tabular}

$\chi^{2}$ Pearson or linear-by-linear $\chi^{2}$ test.

aResults for the cutoff point 6/7. 
Table 2. Crude and adjusted prevalence ratios for presence of depressive symptoms (GDS15, cutoff point 5/6) according to sociodemographic, health related variables and indicators of active aging among elderly people. Veranópolis, RS, Brazil, $2009(n=1,006)$.

\begin{tabular}{|c|c|c|c|c|}
\hline & $\begin{array}{c}\text { Unadjusted PR } \\
(95 \% \mathrm{Cl})\end{array}$ & p-value & $\begin{array}{l}\text { Adjusted PR } \\
(95 \% \mathrm{Cl})\end{array}$ & p-value \\
\hline \multicolumn{5}{|c|}{$1^{\text {st }}$ Block Sociodemographic } \\
\hline \multicolumn{5}{|l|}{ Sex } \\
\hline Male & 1 & $<0.001$ & 1 & $<0.001$ \\
\hline Female & $2.21(1.61-3.01)$ & & $2.14(1.56-2.93)$ & \\
\hline \multicolumn{5}{|l|}{ Age } \\
\hline $60-74$ & 1 & $<0.001$ & 1 & 0.001 \\
\hline$\geq 75$ years & $1.57(1.23-2.01)$ & & $1.51(1.19-1.93)$ & \\
\hline \multicolumn{5}{|l|}{ Family income $(R \$)$} \\
\hline High ( $\geq 2076$ ) & 1 & $<0.001$ & 1 & 0.002 \\
\hline Middle (930 - 2075) & $1.14(0.81-1.60)$ & & $1.04(0.75-1.46)$ & \\
\hline Low (0 - 929) & $1.98(1.40-2.81)$ & & $1.69(1.19-2.39)$ & \\
\hline \multicolumn{5}{|c|}{$2^{\text {nd }}$ Block Health } \\
\hline \multicolumn{5}{|l|}{ Self-rated health } \\
\hline Excellent/very good/good & 1 & $<0.001$ & 1 & $<0.001$ \\
\hline Fair/poor & $3.33(2.49-4.45)$ & & $2.65(1.94-3.61)$ & \\
\hline \multicolumn{5}{|l|}{ Reported Morbidities } \\
\hline No morbidity & 1 & $<0.001$ & 1 & $<0.001$ \\
\hline 1 morbidity & $1.59(1.02-2.49)$ & & $1.18(0.77-1.81)$ & \\
\hline 2 morbidities & $2.53(1.64-3.91)$ & & $1.52(0.98-2.36)$ & \\
\hline$\geq 3$ morbidities & $3.85(2.50-5.93)$ & & $2.06(1.31-3.23)$ & \\
\hline \multicolumn{5}{|c|}{$3^{\text {rd }}$ Block Active Aging } \\
\hline \multicolumn{5}{|l|}{ Occupation status } \\
\hline Not-working & 1 & 0.013 & 1 & 0.038 \\
\hline Working & $0.30(0.11-0.77)$ & & $0.37(0.14-0.94)$ & \\
\hline \multicolumn{5}{|l|}{ Participation in groups } \\
\hline No & 1 & $<0.001$ & 1 & $<0.001$ \\
\hline Yes & $0.39(0.28-0.55)$ & & $0.55(0.39-0.76)$ & \\
\hline \multicolumn{5}{|l|}{ Talking to friends } \\
\hline No & 1 & $<0.001$ & 1 & 0.012 \\
\hline Yes & $0.39(0.27-0.55)$ & & $0.68(0.50-0.93)$ & \\
\hline \multicolumn{5}{|l|}{ Manual work } \\
\hline No & 1 & 0.001 & 1 & 0.029 \\
\hline Yes & $0.64(0.49-0.83)$ & & $0.77(0.60-0.97)$ & \\
\hline \multicolumn{5}{|l|}{ Reading } \\
\hline No & 1 & $<0.001$ & 1 & 0.002 \\
\hline Yes & $0.52(0.41-0.66)$ & & $0.68(0.54-0.86)$ & \\
\hline \multicolumn{5}{|l|}{ Physical Activity ${ }^{b}$} \\
\hline No & 1 & $<0.001$ & 1 & 0.019 \\
\hline Yes & $0.45(0.33-0.60)$ & & $0.71(0.53-0.94)^{c}$ & \\
\hline
\end{tabular}

${ }^{a}$ Variables were adjusted for all other variables in the same block plus the variables from higher blocks. ${ }^{\text {b}}$ Results for GDS15 cutoff point 6/7. 'Adjusted for sex, age, marital status, schooling, self-rated health, morbidities, participation in groups and reading. 


\section{DISCUSSION}

The main aim in this study was to evaluate the association between indicators of active aging and depressive symptoms among elderly people. Those with a more active life presented lower prevalence of depressive symptoms than those who were less active. Active aging is applicable both to individuals and to population groups. It allows people to perceive their potential for physical, social and mental development. It leads to wellbeing throughout life and greater participation in society, according to individuals' needs, desires and capacities. It furnishes adequate protection, security and comfort when these elderly people require care. An active life improves mental health and often promotes social contacts. Being active may help elderly individuals to remain independent for longer periods of time ${ }^{2}$.

We found a strong association between participation in groups and depressive symptoms. A systematic review followed by a meta-analysis showed that social activities (especially those that provide an active role for the participants) contributed significantly to reduction of depressive symptoms and improvement in the mental health and quality of life of the elderly ${ }^{15}$. This result agrees with the findings of a Brazilian study with 1,656 elderly ${ }^{16}$. We considered participation in groups as an indicator of active aging. However, this variable has usually been considered an indicator of social capital $^{17,18}$. In a different analysis with the same data set and using the GDS-30, we reported higher levels of collective efficacy to be associated with lower depressive symptoms ${ }^{19}$.

In our study, elderly individuals who reported working, talking to friends and reading habits had fewer depressive symptoms. A protective effect of paid work, of leisure time activities and of relationship with friends on functional incapacity in retired Brazilian elders has been reported by D'Orsi et al. ${ }^{20}$. The authors suggest these variables could have a protective effect through social support, learning and competition mechanisms that keep workers active. Cognitive deficiency and depressive symptoms are linked and interrelated factors ${ }^{16}$.

Physical activity was related to depressive symptoms when we used a more strict cutoff point of seven or more symptoms. The beneficial effect of physical activity for diminishing depressive states in adults and in elderly people has been reported ${ }^{7,9,16,21}$. Blumenthal et al. ${ }^{22}$ reported that eleven weeks of treatment with aerobic exercises was just as effective as using antidepressants for major depression among individuals aged 50 years or over.

However, the mechanisms through which physical activity would lead to reduction of depression remain unclear. Brosse et al. ${ }^{23}$ argued that this would occur through physiological and psychological mechanisms. With regard to physiological mechanisms, exercises may promote or help in correction of central monoamine levels and hypothalamic-pituitary-adrenal hyperactivity, in response to stress that leads to depression. In other words, exercises may promote changes to the central activity of norepinephrine and increase the secretion of serotonin and endorphin ${ }^{22}$. With regard to psychological mechanisms, active aging may lead to the benefit of mood improvement, with increased self-esteem and positive effects relating to individuals' body image and self-efficacy (i.e. individuals' belief in their capacity to perform specific activities). It may also promote distancing from negative emotions, which is an important component of cognitive-behavioral therapy $^{23}$ and may improve sleep quality and satisfaction with life $\mathrm{e}^{24,25}$. 
One of the limitations of this study relates to the design that was used. Because this was a cross-sectional study, it cannot be determined whether the exposure caused or was a consequence of the outcome. It could be argued both that worse indicators of active aging may lead to depression and that depression, when untreated, may favor greater physical inactivity. For example, a cohort study in the Netherlands concluded that depression is a risk factor for sedentary lifestyles ${ }^{26}$. Crosssectional studies are more appropriate for identifying associations, rather than causal relationships. Moreover, presence of Neyman bias (incidence-prevalence bias) ${ }^{27}$ cannot be discarded. Depressive elders that were not active could have had a shorter life than those who were depressive and active. Thus, they would have less probability to be detected (selected) with the cross-sectional design. As a result, the associations reported here could be underestimated. Therefore, this relationship would be better investigated through prospective studies, in which the indicators of active aging and depression would both be measured repeatedly. In addition, because indicators of active aging were not validated, measurement errors may exist. Therefore, caution must be exercised when interpreting the results of this research. Studies using biological markers or validated instruments reflecting the multidimensional concept of aging active aging are necessary ${ }^{28}$.

The empirical evidence supports the affirmation that depression is not a normal component of aging ${ }^{29}$. Elderly people experience many losses: health, social role, economic power and human relationships. All these losses that they experience make them more vulnerable to depression ${ }^{6}$. This finding emphasizes the need for initiatives that may complement traditional approaches, or that may help to deal with depressive symptoms more naturally, with fewer drugs. This is especially important because drug therapy among elderly people carries greater risk due to treatment of existing comorbidities and consequent greater possibility of side effects caused by drug interactions ${ }^{30}$. The rapid aging of Brazilian population and the increased use of health services poses challenges for policymakers and agencies ${ }^{31,32}$. Health and mental care policies for the elderly should have an integrative approach, including prevention, risk factors and treatment ${ }^{33}$. The associations reported here demonstrate strong and consistent associations between indicators of active aging and fewer depressive symptoms in Brazilian elderly.

\section{CONCLUSION}

Our results suggest that active aging approaches may play an important role in promoting mental health of older adults.

\section{REFERENCES}

1. Prince M, Patel V, Saxena S, Maj M, Maselko J, Phillips $\mathrm{MR}$, et al. No health without mental health. Lancet 2007; 370(9590): 859-77.

2. World Health Organization. Active ageing: a policy framework. Madrid: WHO; 2002.

3. World Health Organization. Mental disorders. Fact sheet $\mathrm{N}^{\circ}$ 396. Geneva: WHO; 2014. Disponível em: http:/ / www.who.int/mediacentre/factsheets/fs396/ en/. (Acessado em 9 de março de 2015).

4. Alexopoulos GS. Depression in the elderly. Lancet 2005; 365(9475): 1961-70.

5. Blazer DG. Depression in late life: review and commentary. J Gerontol A Biol Sci Med Sci 2003; 58(3): 249-65. 
6. Takeda M, Tanaka T. Depression in the elderly. Geriatr Gerontol Int 2010; 10(4): 277-9.

7. Guimarães JMN, Caldas CP. A influência da atividade física nos quadros depressivos de pessoas idosas: uma revisão sistemática. Rev Bras Epidemiol 2006; 9(4): 481-92.

8. Hollon SD, Jarrett RB, Nierenberg AA, Thase ME, Trivedi M, Rush AJ. Psychotherapy and medication in the treatment of adult and geriatric depression: which monotherapy or combined treatment? J Clin Psychiatry 2005; 66(4): 455-68.

9. Barbour KA, Blumenthal JA. Exercise training and depression in older adults. Neurobiol Aging 2005; 26(Suppl 1): 119-23.

10. Montorio I, Izal M. The Geriatric Depression Scale: a review of its development and utility. Int Psychogeriatr 1996; 8(1): 103-12.

11. Almeida OP, Almeida SA. Short versions of the geriatric depression scale: a study of their validity for the diagnosis of a major depressive episode according to ICD-10 and DSM-IV. Int J Geriatr Psychiatry 1999; 14(10): 858-65.

12. Almeida OP, Almeida SA. [Reliability of the Brazilian version of the ++ abbreviated form of Geriatric Depression Scale (GDS) short form]. Arq Neuropsiquiatr 1999; 57(2B): 421-6 [Portuguese].

13. Yesavage JA, Brink TL, Rose TL, Lum O, Huang $\mathrm{V}$, Adey $\mathrm{M}$, et al. Development and validation of a geriatric depression screening scale: a preliminary report. J Psychiatr Res 1983; 17(1): 37-49.

14. Herrmann N, Mittman N, Silver IL, Shulman KI, Busto UA, Shear NH, et al. A validation study of the Geriatric Depression Scale (GDS) short form. Int J Geriatr Psychiat 1996; 11(5): 457-60.

15. Forsman AK, Nordmyr J, Wahlbeck K. Psychosocial interventions for the promotion of mental health and the prevention of depression among older adults. Health Promot Int 2011; 26(Suppl.1 ): 85-107.

16. Borges LJ, Benedetti TRB, Xavier AJ, D’orsi E. Fatores associados aos sintomas depressivos em idosos: estudo EpiFloripa. Rev Saude Publica 2013; 47(4): 1-10.

17. Putnam RD, Leonardi R, Nanetti RY. Making democracy work: Civic traditions in modern Italy. Princeton: Princeton University Press; 1993.

18. Coleman J. Foundations of social theory. Cambridge: Harvard University Press; 1990. p. 300-21.

19. Quatrin LB, Galli R, Moriguchi E, Gastal FL, Pattussi MP. Collective efficacy and depressive symptoms in Brazilian elderly. Arch Gerontol Geriatr 2014; 59(3): 624-9.

20. D’orsi E, Xavier AJ, Ramos LR. Work, social support and leisure protect the elderly from functional loss: EPIDOSO Study. Rev Saude Publica 2011; 45(4): 685-92.
21. Mammen G, Faulkner G. Physical activity and the prevention of depression: a systematic review of prospective studies. Am J Prev Med 2013; 45(5): 649-57.

22. Blumenthal JA, Babyak MA, Moore KA, Craighead WE, Herman S, Khatri P, et al. Effects of exercise training on older patients with major depression. Arch Intern Med 1999; 159(19): 2349-56.

23. Brosse AL, Sheets ES, Lett HS, Blumenthal JA. Exercise and the treatment of clinical depression in adults: recent findings and future directions. Sports Med 2002; 32(12): 741-60.

24. Kritz-Silverstein D, Barrett-Connor E, Corbeau C. Cross-sectional and prospective study of exercise and depressed mood in the elderly: the Rancho Bernardo study. Am J Epidemiol 2001; 153(6): 596-603.

25. Ruuskanen JM, Ruoppila I. Physical activity and psychological well-being among people aged 65 to 84 years. Age Ageing 1995; 24(4): 292-6.

26. van Gool CH, Kempen GI, Penninx BW, Deeg DJ, Beekman AT, van EijkJT. Relationship between changes in depressive symptoms and unhealthy lifestyles in late middle aged and older persons: results from the Longitudinal Aging Study Amsterdam. Age Ageing 2003; 32(1): 81-7.

27. Neyman J. Statistics: servant of all sciences. Science 1955; 122(3166): 401-6.

28. Zaidi A, Gasior K, Hofmarcher MM, Lelkes O, Marin B, Rodrigues R, et al. Active ageing index 2012. Concept, methodology and final results. Viena: European Centre Viena; 2013.

29. Fiske A, Wetherell JL, Gatz M. Depression in older adults. Annu Rev Clin Psychol 2009; 5:3 63-89.

30. Scalco MZ. Tratamento de idosos com depressão utilizando tricíclicos, IMAO, ISRS e outros antidepressivos. Rev Bras Psiquiatr 2002; 24(Supl I): 55-63.

31. Veras RP. [Disease prevention in the elderly: misconceptions in current models]. Cad Saude Publica 2012; 28(10): 1834-40 [Portuguese].

32. Veras RP. [International experiences and trends in health care models for the elderly]. Cien Saude Colet 2012; 17(1): 231-8 [Portuguese].

33. Veras RP. [Chronic disease management: mistaken approach in the elderly]. Rev Saude Publica 2012; 46(6): 929-34 [Portuguese].

Received on: 05/30/2014

Final version presented on: 03/17/2015

Accepted on: 03/30/2015 